\title{
Screening of Multidrug Resistant Salmonella spp from Potable Water Collected from the Slum Areas of Bhopal, M.P. India
}

\author{
Kamlesh Kumar Ahirwar and Rajesh Kumar Tenguria* \\ Department of Microbiology Government MVM Bhopal MP, India \\ *Corresponding author
}

\begin{abstract}
A B S T R A C T
Salmonella is a most significant pathogenic bacteria causing typhoid and non-typhoidal Salmonellosis. Contaminated food and water consumption is one of the vital modes of

\section{Keywords}

Drinking Water, Salmonella, Antibiotic

Resistance

\section{Article Info}

Accepted:

05 January 2020

Available Online:

10 February 2020

Salmonella transmission cause illness in both human and animals, resulting about 93.8 million causes worldwide annually. Asian and African nations are viewed as the hugest gathering of patients contaminated with waterborne microbial infection. Antibiotic resistance in drinking water sources is of genuine grave concern. The present investigation was aimed at screening of antibiotic resistant Salmonella spp. incident in potable water collected from the some of the slum areas of Bhopal City, M.P. India. Water consumed by the slums when test was reported with higher number of microbial load even at the as low as $10^{-7}$ dilution of water samples. The Salmonellas spp. from water was selectively isolated on bismuth sulphide agar media followed by Gram's staining, microscopy \& biochemical characterization. The 10 different isolates of Salmonellas spp. shows a difference in their diversity based on the resistance towards the particular type of antibiotics. The Salmonella isolated from different sample sources showed resistance towards at least 1 antibiotic and maximum 4 antibiotics. $80 \%$ of the isolates of Salmonella spp. screened from potable drinking water collected from slum areas were reported to show resistance towards the important antibiotics commonly prescribed by medical practitioners is the serious issue of concern.
\end{abstract}

\section{Introduction}

Salmonella is a most significant pathogenic bacteria causing typhoid and non-typhoidal Salmonellosis. Salmonella species are most frequently reported cause of foodborne illness in both humans and animals, resulting about 93.8 million causes worldwide annually (Majowicz, 2010 \& Gillespie, 2003) whereas in developing countries like India, foodborne illness are mostly under reported; however in the past 29 years (1980-2009) 3485 persons have been affected from 37 Salmonella related outbreaks (Sudershan, 2012).

Salmonellae are gram negative, non-lactose fermenting and non-sporing bacteria. With exception of Salmonella pullorum and Salmonella gallinarum, all Salmonellae are actively motile (Cheesbrough, 2000). 
Contaminated food and water consumption is one of the vital modes of Salmonella transmission (D'Aoust, 1989; Quinn et al., 2002; Brooks et al., 2015).

As indicated by CDC, 1999 hosts for nontyphoidal salmonellosis including dairy cattle, swine, poultry, wild winged animals, and pets discharge this life form in dung, which can defile water, different nourishment sources and condition. Salmonella contaminations are grouped into clinical classifications are as following, Salmonellosis, gastroenteritis, bacteremia, osteomyelitis, reactive arthritis, enteric fever and food poisoning (Owens, 2009 \&Klotchko, 2009 and Johnson, 2012).

The significant hotspots for transmitting Salmonella species to human with $40 \%$ of the clinical cases ascribed to the utilization of egg and poultry items (Chashni, 2009 \&Ruban, 2010). Salmonella disease in people is chiefly brought about by drinking water tainted with emissions and defecation of infected faunae (Zahraei, 2000; Quinn et al., 2002; Winn et al., 2006; Motlagh et al., 2013).

As indicated by Seas et al., (2000) kids under five years-age, primarily in Asian and African nations are viewed as the hugest gathering of patients contaminated with waterborne microbial infection.

As per writing, the setting of antibiotic resistance in drinking water sources is of genuine grave concern(Jiang et al., 2013; Flores et al., 2014; Guo et al., 2014; Machado and Bordalo, 2014; Mohanta and Goel, 2014).

The antibacterial estimation of medications is compromised intensely by the expanded pervasiveness of resistant microorganisms (Grabow et al., 1974 \&Hinshaw et al, 1969). Considering the source water is legitimately related with anthropogenic activity and wellbeing, understanding the predominance of antibiotic resistance in human drinking water sources is vital (Chen et al., 2017).

In view of the facts mentioned the present investigation was aimed at screening of antibiotic resistant Salmonella spp. incident in potable water collected from the some of the slum areas of Bhopal City, M.P. India.

\section{Materials and Methods}

Sample Collection Total 10 potable water samples were collected from different area of Bhopal. 50ml of each sample were collected from the sites in a clean, dry and sterile containers using aseptic condition. Details of the collected sample are given table 1 .

\section{CUF (Colony Forming Unit) Count}

The collected water samples were subjected to total bacterial count by inoculating $0.1 \mathrm{ml}$ of water from collected samples on nutrient agar media plates followed by incubation at $37^{\circ} \mathrm{C}$ for 24 hours. To have the idea of contamination on quantitative basis following formulae was used;

CFU per $m l=$ No. of CFU /Total Vol. Plated $\times$ Dilution factor

\section{Screening and isolation of Salmonella species}

Referring to the aim of study Salmonella spp. were used to selectively isolate on Bismuth Sulphite Agar Media. $0.1 \mathrm{ml}$ of water from each collected samples were aseptically transferred on to the separated media plates and spreaded with the help of plastic spreader thereafter incubated at $37^{\circ} \mathrm{C}$. After 24 hours of incubation jet black, surrounded by metallic sheen, convex type colonies were picked for pure culture preparation by transferring them on to the fresh media. 
Table.1 Details of collected sample from different regions

\begin{tabular}{|c|l|c|l|}
\hline S.N. & Sample & Sample Code & Regions \\
\hline $\mathbf{1}$ & Portable water & S-1 & Anna Nagar Bhopal \\
\hline $\mathbf{2}$ & Portable water & S-2 & BarkherhaPathani Bhopal \\
\hline $\mathbf{3}$ & Portable water & S-3 & Habibjang Slum Area Bhopal \\
\hline $\mathbf{4}$ & Portable water & S-4 & Narela Bhopal \\
\hline $\mathbf{5}$ & Portable water & S-5 & Bhim Nagar Bhopal \\
\hline $\mathbf{6}$ & Portable water & S-6 & NayaBasera Bhopal \\
\hline $\mathbf{7}$ & Portable water & S-7 & Kalpana Nagar Indrapuri Bhopal \\
\hline $\mathbf{8}$ & Portable water & S-8 & Neelbad Bhopal \\
\hline $\mathbf{9}$ & Portable water & S-9 & Meera Nagar Bhopal \\
\hline $\mathbf{1 0}$ & Portable water & S-10 & Jhatkhedi Bhopal \\
\hline
\end{tabular}

\section{Characterization of isolates}

The pure cultures of selectively isolated Salmonella spp. were subjected of morphological and microscopic characterization. Also, the biochemical tests like gram reaction, catalase test, gelatin hydrolysis, starch hydrolysis, IMViC test and TSI test were conducted for characterization (Cappuccino and Sherman, 1992).

\section{Screening \& Conformation Antibiotic Resistanc}

The pure isolates of Salmonella spp. collected from different places were subjected to antimicrobial susceptibility assay using octadisc set of antibiotics (HiMedia, India Pvt Ltd). The isolates were first cultures in nutrient broth for 24 hours at $37^{\circ} \mathrm{C}$ followed by swabbing them on to the freshly prepared nutrient agar plates. After this, an antibiotic octadisc was carefully placed on the preinoculated media surface aseptically. The plates were observed for absence of inhibitory zone around particular antibiotic discs as an indicator for drug resistance.

\section{Results and Discussion}

The presence of pathogenic microbes in water bodies is the issues of serious concern where total microbial load per $\mathrm{ml}$ and presence of antibiotic resistant bacteria shall be the matter of tests. The present study was intended to investigate the total microbial load in the potable water collected from the slum areas of various regions of Bhopal City.

\section{Results of CUF Count in water samples}

With reference to observed results of $\mathrm{CFU}$ count as depicted in table 2 of this article it is clear that the water consumed by the slums is loaded with higher number of microbial load even at the as low as $10^{-7}$ dilution of water samples. Sample S-6 was reported to have the lowest total CFU count at $10^{-7}$ dilution as 01 followed by S-5, S-8 and S-2 as 05,06 and 08 CFU counts respectively. S-3, S-4 and S-9 
were with higher CFU count as 45, 38 and 24 respectively.

Contaminated water plays an important role in diseases transmission and it performs a vital role in the public health and survival of organisms, especially in rural areas of developing countries (Makoni et al., 2004; Pant, 2004; Katsi et al., 2007).

People from developing countries encountered with higher risk of water-borne diseases as compared to the developed countries (Simpson et al., 2002). Based on the report of World Health Organization (WHO), the mortality rate of diseases related to contaminated water is more than 5 million people per year.

Nowadays, efforts to attain higher quality of drinking water were emphasized, (WHO, 2008).

On global scale, drinking water pollution by pathogens is evaluated the most important risk for human health, and also it has been lead to numerous outbreaks of diseases and poisoning (WHO, 2008). Therefore this study evaluates salmonella from drinking water source to determine to portability of the water.

\section{Biochemical Characterization}

The bacterial isolates of Salmonella spp. selectively isolated from the collected waters samples on bismuth sulphate agar media were subjected to number of biochemical tests the outcomes or observations of which are depicted in table 3.

Refereeing to the outcomes of the of biochemical tests the bacterial isolates were confirmed as Salmonellas spp. and becomes the matter of concerns in the sense that, the potable water used by the slums is flooded with the variety of Salmonella spp. and thus the population is prone to serious illness due to water born salmonellosis.

Identification of Salmonella spp. can be performed via both biochemical and molecular methods. In present work biochemical test parameters were considered for characterization of salmonella isolates according to Barrow, (2003).

Table.2 Total bacterial count of spread plate technique after incubation

\begin{tabular}{|l|c|c|c|c|c|c|c|c|c|c|}
\hline $\begin{array}{l}\text { Dilutions } \\
\text { Used }\end{array}$ & S-1 & S-2 & S-3 & S-4 & S-5 & S-6 & S-7 & S-8 & S-9 & S-10 \\
\hline $\mathbf{1 0}^{-3}$ & 148 & 78 & 214 & 311 & 56 & 39 & 142 & 68 & 307 & 181 \\
\hline $\mathbf{1 0}^{-5}$ & 59 & 23 & 122 & 189 & 20 & 21 & 37 & 15 & 93 & 42 \\
\hline $\mathbf{1 0}^{-\mathbf{7}}$ & 11 & 08 & 45 & 38 & 05 & 01 & 13 & 06 & 24 & 13 \\
\hline
\end{tabular}


Table.3 Results of biochemical test

\begin{tabular}{|c|c|c|c|c|c|c|c|c|c|c|c|}
\hline \multirow{2}{*}{ S.N. } & \multirow{2}{*}{$\begin{array}{c}\text { Tests } \\
\text { Conducted }\end{array}$} & \multicolumn{10}{|c|}{ Samples Codes } \\
\hline & & S-1 & S-2 & S-3 & S-4 & S-5 & S-6 & S-7 & S-8 & S-9 & S-10 \\
\hline 1. & $\begin{array}{l}\text { Gram's } \\
\text { staining }\end{array}$ & $-\mathrm{ve}$ & $-\mathrm{ve}$ & $-\mathrm{ve}$ & $-\mathrm{ve}$ & $-\mathrm{ve}$ & $-\mathrm{ve}$ & $-\mathrm{ve}$ & $-\mathrm{ve}$ & $-\mathrm{ve}$ & $-\mathrm{ve}$ \\
\hline 2. & $\begin{array}{c}\text { Cell } \\
\text { Morphology }\end{array}$ & Bacillus & Bacillus & Bacillus & Bacillus & Bacillus & Bacillus & Bacillus & Bacillus & Bacillus & Bacillus \\
\hline 3. & Catalase Test & $+\mathrm{ve}$ & $+\mathrm{ve}$ & $+\mathrm{ve}$ & $+\mathrm{ve}$ & $+\mathrm{ve}$ & $+\mathrm{ve}$ & $+v e$ & $+\mathrm{ve}$ & $+\mathrm{ve}$ & $+\mathrm{ve}$ \\
\hline 4. & Oxidase Test & $-\mathrm{ve}$ & $-\mathrm{ve}$ & $-\mathrm{ve}$ & $-\mathrm{ve}$ & $-v e$ & $-\mathrm{ve}$ & $-v e$ & $-v e$ & $-\mathrm{ve}$ & $-\mathrm{ve}$ \\
\hline 5. & Indole Test & $-\mathrm{ve}$ & $-\mathrm{ve}$ & $-\mathrm{ve}$ & $-\mathrm{ve}$ & $-\mathrm{ve}$ & $-\mathrm{ve}$ & $-\mathrm{ve}$ & $-\mathrm{ve}$ & $-\mathrm{ve}$ & $-\mathrm{ve}$ \\
\hline 6. & MR test & $+\mathrm{ve}$ & $+\mathrm{ve}$ & $+\mathrm{ve}$ & $+\mathrm{ve}$ & $+\mathrm{ve}$ & $+\mathrm{ve}$ & $+v e$ & $+\mathrm{ve}$ & $+\mathrm{ve}$ & $+\mathrm{ve}$ \\
\hline 7. & VP Test & $-\mathrm{ve}$ & $-\mathrm{ve}$ & $-\mathrm{ve}$ & $-\mathrm{ve}$ & $-v e$ & $-\mathrm{ve}$ & $-\mathrm{ve}$ & $-\mathrm{ve}$ & $-\mathrm{ve}$ & $-\mathrm{ve}$ \\
\hline 8. & Citrate Test & $-\mathrm{ve}$ & $-v e$ & $-\mathrm{ve}$ & $-\mathrm{ve}$ & $-\mathrm{ve}$ & $-\mathrm{ve}$ & $-\mathrm{ve}$ & $-\mathrm{ve}$ & $-\mathrm{ve}$ & $-\mathrm{ve}$ \\
\hline 9. & TSI Test & $\mathrm{K} / \mathrm{A}$ & K/A & $\mathrm{K} / \mathrm{A}$ & $\mathrm{K} / \mathrm{A}$ & $\mathrm{K} / \mathrm{A}$ & $\mathrm{K} / \mathrm{A}$ & K/A & $\mathrm{K} / \mathrm{A}$ & $\mathrm{K} / \mathrm{A}$ & $\mathrm{K} / \mathrm{A}$ \\
\hline 10. & $\begin{array}{c}\mathrm{H}_{2} \mathrm{~S} \\
\text { Production }\end{array}$ & $+\mathrm{ve}$ & $+\mathrm{ve}$ & $+\mathrm{ve}$ & $+\mathrm{ve}$ & $+\mathrm{ve}$ & $+v e$ & $+\mathrm{ve}$ & $+\mathrm{ve}$ & $+\mathrm{ve}$ & $+\mathrm{ve}$ \\
\hline 11. & $\begin{array}{c}\text { Gas } \\
\text { Production }\end{array}$ & $-\mathrm{ve}$ & $-\mathrm{ve}$ & $-\mathrm{ve}$ & $-\mathrm{ve}$ & $-\mathrm{ve}$ & $-\mathrm{ve}$ & $-\mathrm{ve}$ & $-\mathrm{ve}$ & $-\mathrm{ve}$ & $-\mathrm{ve}$ \\
\hline 12. & $\begin{array}{c}\text { Sucrose } \\
\text { Fermentation }\end{array}$ & $-\mathrm{ve}$ & $-\mathrm{ve}$ & $-\mathrm{ve}$ & $-\mathrm{ve}$ & $-\mathrm{ve}$ & $-\mathrm{ve}$ & $-\mathrm{ve}$ & $-\mathrm{ve}$ & $-\mathrm{ve}$ & $-\mathrm{ve}$ \\
\hline 13. & $\begin{array}{c}\text { Fructose } \\
\text { Fermentation }\end{array}$ & $-\mathrm{ve}$ & $-\mathrm{ve}$ & $-\mathrm{ve}$ & $-\mathrm{ve}$ & $-\mathrm{ve}$ & $-\mathrm{ve}$ & $-\mathrm{ve}$ & $-\mathrm{ve}$ & $-\mathrm{ve}$ & $-\mathrm{ve}$ \\
\hline 14. & $\begin{array}{c}\text { Lactose } \\
\text { Fermentation }\end{array}$ & $-\mathrm{ve}$ & $-\mathrm{ve}$ & $-\mathrm{ve}$ & $-\mathrm{ve}$ & $-\mathrm{ve}$ & $-\mathrm{ve}$ & $-\mathrm{ve}$ & $-\mathrm{ve}$ & $-\mathrm{ve}$ & $-\mathrm{ve}$ \\
\hline 15. & $\begin{array}{c}\text { Mannitol } \\
\text { Fermentation }\end{array}$ & $+\mathrm{ve}$ & $+\mathrm{ve}$ & $+\mathrm{ve}$ & $+\mathrm{ve}$ & $+\mathrm{ve}$ & $+\mathrm{ve}$ & $+\mathrm{ve}$ & $+\mathrm{ve}$ & $+\mathrm{ve}$ & $+\mathrm{ve}$ \\
\hline 16. & $\begin{array}{c}\text { Glucose } \\
\text { Fermentation }\end{array}$ & $+\mathrm{ve}$ & $+\mathrm{ve}$ & $+\mathrm{ve}$ & $+\mathrm{ve}$ & $+\mathrm{ve}$ & $+\mathrm{ve}$ & $+\mathrm{ve}$ & $+\mathrm{ve}$ & $+\mathrm{ve}$ & $+\mathrm{ve}$ \\
\hline
\end{tabular}

\section{Antimicrobial resistant activity}

Antibiotic resistance is a global public health concern (Tule, 2017). Antibiotic-resistant bacteria as the etiology of infection have been escalating at adistressing rate (Fair, 2014). It is indicated that almost 1 crores people will die annually due to antimicrobial resistance (AMR) infections (Mckenna, 2014).

The antibiotics towards which the resistance of indigenous Salmonella isolates was investigated at particular concentration by disc diffusion technique using octadisc are depicted in table 4. The 10 different isolates of Salmonellas spp. shows a difference in their diversity based on the resistance towards the particular type of antibiotics. It was observed that sample S-7 showed resistance towards 5 antibiotics namely Ampicillin, Cotrimoxazole, Erythromycin, and Cephalexin while S-10 also was also resistant for Ampicillin, Tetracycline Erythromycin, and Cephalexin.

Samples S-1 and S-3 were reported to show resistance towards Ampicillin, Cotrimoxazole, Ciprofloxacin as set and Ciprofloxacin, Erythromycin, Cephalexin as set. Resistance for Ampicillin and Cephalexin was observed common in S-4 and S-9 Salmonella isolates while Samples S-5 \& S-8 
was inhibited by all the antibiotics present on the octa disc. The antibiotic observes ineffective against most of the isolates was Ampicillin \& Cephalexin followed by Ciprofloxacin, Cotrimoxazole\& Erythromycin then Tetracycline.

Salmonella is hard to wipe out from its reservoir hosts, and food animals frequently serve as reservoirs of the pathogen. NontyphoidalSalmonella causes the most noteworthy number of sicknesses, hospitalizations, and passings related with foodborne ailment (Scallan, et al., 2011).

The circumstance exasperated, when antibiotic-resistant clones oftentimes inferred as the etiological operators in these flare-ups leads to treatment disappointments, higher risk of bloodstream infections, and amplified rate of hospitalizations (Nair, et al., 2018).

In prior examinations Taban, et al., (2013) while working with prepared to eat serving of mixed greens vegetable examples screened out the assorted variety of antibioticresistantS. enterica using RAPD-PCR examinations.

White, (2001) announced salmonella pollution in $20 \%$ of the meet samples they investigated where $84 \%$ isolated were resistant to at least one antibiotic, and 53\% were resistant to at least three antibiotics tried.

Similarly, Kebede, et al., (2016) led a crosssectional investigation to evaluate the degree of Salmonella contamination in butchered bovines and ovines at Addis Ababa abattoir where out of 280 animals they examined, $4.64 \%$ ( 8 bovines and 5 ovines) were sure, with most examples $(12 / 13,92 \%)$ including Salmonella Dublin; 69\% of all separates were resistant to multiple antibiotics especially human medicine at high level.

In present study also, $80 \%$ of the isolates of Salmonella sppscreened from potable drinking water collected from slum areas of Bhopal City, India were reported to show resistance towards the important antibiotics commonly prescribed by medical practitioners is the serious issue of concern.

Table.4 Set of antibiotics used on octadisc with their concentrations on disc

\begin{tabular}{|l|l|l|}
\hline S.N. & Antibiotic used & Concentration on Disc \\
\hline 1. & Ampicillin & $10 \mu \mathrm{g}$ \\
\hline 2. & Gentamycin & $30 \mu \mathrm{g}$ \\
\hline 3. & Cephalexin & $25 \mu \mathrm{g}$ \\
\hline 4. & Erythromycin & $05 \mu \mathrm{g}$ \\
\hline 5. & Tetracycline & $10 \mu \mathrm{g}$ \\
\hline 6. & Chloramphenicol & $15 \mu \mathrm{g}$ \\
\hline 7. & Cotrimoxazole & $30 \mu \mathrm{g}$ \\
\hline 8. & Ciprofloxacin & $30 \mu \mathrm{g}$ \\
\hline
\end{tabular}


Table.5 Resistance observed by indigenous Salmonella isolates towards the antibiotics use on present work

\begin{tabular}{|r|r|l|}
\hline S.N. & Salmonella Isolates & Resistant towards Antibiotics \\
\hline $\mathbf{1 .}$ & $\mathbf{S - 1}$ & Ampicillin, Cotrimoxazole, Ciprofloxacin, \\
\hline $\mathbf{2 .}$ & $\mathbf{S - 2}$ & Ciprofloxacin \\
\hline $\mathbf{3 .}$ & $\mathbf{S - 3}$ & Ciprofloxacin, Erythromycin, Cephalexin \\
\hline $\mathbf{4 .}$ & $\mathbf{S - 4}$ & Ampicillin, Cephalexin \\
\hline $\mathbf{5 .}$ & $\mathbf{S - 5}$ & No Resistance \\
\hline $\mathbf{6 .}$ & $\mathbf{S - 6}$ & Cotrimoxazole, Ciprofloxacin \\
\hline $\mathbf{7 .}$ & $\mathbf{S - 7}$ & Ampicillin, Cotrimoxazole, Erythromycin, Cephalexin \\
\hline $\mathbf{8 .}$ & $\mathbf{S - 8}$ & No Resistance \\
\hline $\mathbf{9 .}$ & $\mathbf{S - 9}$ & Ampicillin, Cephalexin \\
\hline $\mathbf{1 0}$ & $\mathbf{S - 1 0}$ & Ampicillin, Tetracycline Erythromycin, Cephalexin \\
\hline
\end{tabular}

Ampicillin, Ciprofloxacin, Erythromycin, Chloramphenicol and Cotrimoxazole are the common antibiotics used in the treatment of typhoidal and non typhoidal diseases, hence the incidence of the isolated showing resistance towards these specific antibiotics possess serious threat of contracting Salmonellosis among the population using contaminated water.

With due concern to the public health, it is advisable that water supplies in the slum areas must be maintained with hygiene and also the families must take measures to make water microbial contamination free like use of alum and chlorine tablets or at least boiling \& filtration before consumption.

\section{Acknowledgement}

The authors would like to pay sincere thanks to the collogues for their constant moral support and authors would also like to show their gratitude towards Mr. MayankTenguria Director of Lenience Biotech Lab, Bhopal,
MP, India for providing necessary laboratory facility and scientific guidance to conduct this significant piece of research investigation.

\section{References}

Barrow, G. I. and Feltham, R. K. A. (2003). Cowan and Steel's manual for the identification of medical bacteria. Cambridge University Press, 3rd edition.

Bisi-Johnson, M.A. and Obi, C.L. (2012) Escherichia coli and Salmonella species: Molecular landscape and therapeutic considerations: A review. Adv. Med. Sci.;1(1): 1-16.

Brooks GF, Carroll KC, Butel JS, Morse SA, Mietzner TA (2015); Jawetz, Melnick, and Adelberg's Medical Microbiology, 26 ed. McGraw-Hill Education. USA.

CDC. (1999); Section VII-agents summary statements, section VIIA bacterial agents. In: Richmond, J.Y. and McKinney, R.W., editors. Biosafety in Microbiological and Biomedical 
Laboratories.4th ed. Government Printing Office, Washington, U.S. p109. Chashni, E., Hassanzadeh, S. H., M., Fard, B. and Mirz, S. (2009) .Characterization of the Salmonella isolates from backyard chickens in north of Iran, by serotyping, multiplex PCR and antibiotic resistance analysis. Razi Vaccine \& Serum Research; 64 (2):7783.

Cheesbrough, M. (2000); District laboratory practice in tropical countries. Cambridge University Press, 2nd edition.

Chen Z, Yu D, He S, Ye H, Zhang L, Wen Y, Zhang W, Shu L and Chen S (2017) Prevalence of Antibiotic-Resistant Escherichia coli in Drinking Water Sources in Hangzhou City. Front. Microbiol. 8:1133. doi: 10.3389/fmicb.2017.01133.

D'Aoust JY (1989); Salmonella. In: Doyle MP (Ed.), Foodborne Bacterial Pathogens. CRC Press. pp. 327-445.

Fair, R.J. and Tor, Y. (2014) Antibiotics and bacterial resistance in the $21 \mathrm{st}$ century.Perspect. Med. Chem., 6: 14459.

Flores Ribeiro, A., Bodilis, J., Alonso, L., Buquet, S., Feuilloley, M., Dupont, J. P., et al., (2014).Occurrence of multiantibiotic resistant Pseudomonas spp. In drinking water produced from karstichydrosystems. Sci. Total. Environ. 490, 370-378. doi: 10.1016/j.scitotenv.2014.05.012.

Gillespie, B. E., Mathew, A. G., Draughon, F. A., Jayarao, B. M. and Oliver, S. P. (2003) Detection of Salmonella enterica somatic groups $\mathrm{C} 1$ and $\mathrm{E} 1$ by PCRenzyme-linked immunosorbent assay. J. Food Prot.; 66: 2367-2370.

Grabow, W. 0.K., 0. W. Prozesky, and L. S. Smith. 1974. Drug resistant coliforms call for review of water quality standards. Water Res. 8:1-9.
Guo, X., Li, J., Yang, F., Yang, J., and Yin, D. (2014). Prevalence of sulfonamide and tetracycline resistance genes in drinking water treatment plants in the Yangtze River Delta, China. Sci. Total Environ. 493, 626-631. doi: 10.1016/j.scitotenv.2014.06.035.

Hinshaw, V., J. Punch, M. J. Allison, and H. P. Dalton. 1969. Frequency ofR-factormediated multiple drug resistance in Klebsiella and Aerobacter. Appl. Environ Microbiol. 17:214-218.

Jiang, L., Hu, X., Xu, T., Zhang, H., Sheng, D., and Yin, D. (2013). Prevalence of antibiotic resistance genes and their relationship with antibiotics in the Huangpu River and the drinking water sources, Shanghai, China. Sci. Total Environ. 458-460, 267-272. doi: 10.1016/j.scitotenv.2013.04.038.

Katsi L, Siwadi J, Guzha E, Makoni FS, Smits S (2007) Assessment of factor which affect multiple uses of water sources at household level in rural Zimbabwe.A case study of Marondera, Murehwa and UzumbaMarambaPfungwe districts. Physics and Chemistry of the Earth 32 : 1157-1166.

DOI: http://dx.doi.org/10.1016/j.pce.2007.07. 010.

Kebede, A., Kemal, J., Alemayehu, H., and Mariam, S.H., (2016). Isolation, Identification, and Antibiotic Susceptibility Testing of Salmonellafrom Slaughtered Bovines and Ovines in Addis Ababa Abattoir Enterprise, Ethiopia: A Cross-Sectional Study. International Journal of Bacteriology; 2016: 3714785. Published online $2016 \quad$ Aug 29. doi: $10.1155 / 2016 / 3714785$.

Klotchko, A. and Wallace, M.R. (2009) Salmonellosis: Treatment and Medication. Available from: http://www. 
emedicine.medscape.com/article/22817

4-overview. Accessed on 15-04-2015.

Machado, A., and Bordalo, A. A. (2014).

Prevalence of antibiotic resistance in bacteria isolated from drinking well water available in Guinea-Bissau (West Africa). Ecotoxicol. Environ. Saf. 106, 188-194.

doi: 10.1016/j.ecoenv.2014.04.037.

Majowicz, S.E., Musto, J., Scallan, E., Angulo, F.J., Kirk, M., O’Brien, S.J. and Hoekstra, R.M. (2010); The global burden of non-typhoidal Salmonella gastroenteritis. Clin. Infect. Dis., 50(6): 882-889.

Makoni FS, Manase G, Ndamba J (2004) Patterns of domestic water use in rural areas of Zimbabwe, gender roles and realities. Physics and Chemistry of the Earth 29: 1291-1294. DOI: http://dx.doi.org/10.1016/j.pce.2004.09. 013.

Mckenna, M. (2014) The Coming Cost of Superbugs: 10 Million Deaths Per Year. Available from: http://www.wired. com/2014/12/oneill-rptamr. Last accesed on 10.01.2019

Mohanta, T., and Goel, S. (2014).Prevalence of antibiotic-resistant bacteria in three diff erent aquatic environments over three seasons. Environ. Monit. Assess. 186, 5089-5100. doi: 10.1007/s10661014-3762-1.

Motlagh H, tavakoli HR, Dabaghmoghadam A, Cheraghi N, Akbarin HA (2013) Assessment of Bactaslide media in diagnosis of Salmonella in water and foods in comparison with standard method in order to use in crisis. Annals of Military and Health Sciences Research 11:114-119 (Text in Persian).

Nair, D.V.T., Kumar Venkitanarayanan, and AnupKollanoorJohny

(2018).Antibiotic-

Resistant Salmonella in the Food Supply and the Potential Role of
Antibiotic Alternatives for

Control.Foods; $\quad$ 7(10): 167. https://doi.org/10.3390/foods7100167.

Owens, M.D. and Warren, D.A. (2009) Salmonella Infection. Emedicine: Emergency MedicineAvailable from: http://www.emedicine.medscapecom/art icle/785774-overview.html. Accessed on 15-04-2015.

Pant PR (2004) Tailored media for the detection of E.coli and coliforms in the water sample. Tribhuvan University Journal 24: 49-54

Quinn PJ, Markey BK, Carter ME, Donnelly WJ, Leonard FC (2002); Veterinary Microbiology and Microbial Disease.Iowa State University Press, Ames, Iowa, USA.

Ruban, S., Thyiageeswaran, M and Sharadha, R. (2010).Isolation and Identification of Salmonellaspp from Retail Chickens by Polymerase Chain Reaction.Journal of Microbiology Research; 1(3):106-109.

Scallan E., Hoekstra R.M., Angulo F.J., Tauxe R.V., Widdowson M.-A., Roy S.L., Jones J.L., Griffin P.M. (2011). Foodborne illness acquired in the United States-Major pathogens. Emerging Infectious Diseases journal; 17: 7-15. doi: 10.3201/eid1701.P11101.

Seas C, Alarcon M, Aragon JC, Beneit S, Quiñonez M, Guerra H, Gotuzzo E (2000) Surveillance of Bacterial Pathogens Associated with Acute Diarrhea in Lima, Peru. International Journal of Infectious Diseases 4: 96-99. DOI: http://dx.doi.org/10.1016/S12019712(00)90101-2.

Simpson JM, Santo Domingo JW, Reasoner DJ (2002) Microbial source tracking, state of the science. Environmental Science Technology 36: 5279-5288.

Sudershan, R.V., Kumar, R.N. and Polasa, K. (2012) Foodborne diseases in India - A review. Br. Food J., 114(5): 661-680.

Taban, B.M., Aytac, S.A.,Akkoc, 
N.,andAkcelik, (2013).Characterization of Antibiotic Resistance in Salmonella enterica Isolates Determined from Ready-to-Eat (RTE) Salad Vegetables. Brazilian Journal

Microbiology; 44(2): 391. Published online 2013 Oct 30. doi: 10.1590/S151783822013005000047.

Tule, A. and Hassani, U. (2017) Colonization with antibiotic-resistant $\mathrm{E}$. coli in commensal fecal flora of newborns. Int. J. Curr. Microbiol. Appl. Sci., 6(5): 1623-1629.

White, D.G., (2001). The Isolation of Antibiotic-Resistant Salmonella from
Retail Ground Meats.The New England Journal of Medicine; 345(16):11471154. DOI: 10.1056/NEJMoa010315.

Winn WJr, Allen S, Janda W, Koneman E, Procop G, Schreckenberger P, Woods G (2006) Koneman's Color atlas and textbook of diagnostic microbiology. 6th ed. Lippincott Williams and Wilkins.

World Health Organization (WHO) (2008); Guidelines for Drinking-water Quality, Incorporating 1st and 2nd Addenda, Volume 1, Recommendations, 3rd ed. WHO: Geneva, Switzerland.

ZahraeiSalehi T (2000) Salmonella. Tehran University Press, Tehran.

\section{How to cite this article:}

Kamlesh Kumar Ahirwar and Rajesh Kumar Tenguria. 2020. Screening of Multidrug Resistant Salmonella spp from Potable Water Collected from the Slum Areas of Bhopal, M.P. India. Int.J.Curr.Microbiol.App.Sci. 9(02): 409-415. doi: https://doi.org/10.20546/ijcmas.2020.902.051 